\title{
ON THE CHANGE OF WORD STRESS \\ IN THE HISTORY OF GERMAN*
}

\begin{abstract}
Word stress in German is usually thought of as following the Germanic stress pattern (main stress on first stem syllable); quasi-monomorphemic words like Forélle or Holúnder suggest, however, that Modern German follows a Latinate stress pattern (last syllable extrametrical; stress on the penultima or the antepenultima, depending on weight of the second-to-last syllable). The change in stress pattern occurred in the $16^{\text {th }}$ and $17^{\text {th }}$ century, judging from evidence of metrical texts, due to a heavy influx of Latin and Romance loan words in this period, which followed the Latinate stress pattern and were taken as sample for the stressing of monomorphemic words longer than two syllables.
\end{abstract}

\section{Introduction}

\subsection{Overview}

German word stress in native words has been analyzed as following a >Germanic< stress pattern, that is: a pattern which assigns the main word stress always to the first syllable (excluding certain prefixes). If this is true, a German language learner would need a second rule system to assign word stress to foreign words such as e.g. Minúte (`minute $<$ ) or Ingenieúr (>engineer $`$ ). While this is in itself not a problem (English speakers for instance clearly need several competing stress systems), it is not as attractive as a unified system would be on conceptual grounds. The evidence of native monomorphemic words that are longer than three syllables in Modern German (such as Forélle >trout<) suggest that in fact German word stress follows a single system, and that this system is certainly not the Germanic system, but the Latin stress system. The change towards the Latin stress system occurred, judging from evidence from metrical texts (they are chosen as data source because there it is possible to determine word stress), in the Renaissance and Early baroque period, a time, in which we see a heavy influx of loanwords into

\footnotetext{
* I would like to thank Eugene Buckley, Jean-Francois Mondon, Marga Reis and Beatrice Santorini for their invaluable help during the composition of this paper. All remaining errors are my own responsibility.
} 
German coming from languages that follow the Latin stress pattern. This paper is concerned with the details of this process.

\subsection{Analyses of the Recent System}

It was rather common until the 1960s to analyse Modern German word stress on the lines of the stress pattern which can be reconstructed for Proto-Germanic: ${ }^{1}$ The main stress falls on the first syllable of the stem of the word, thus preventing the stress from falling on prefixes such as $b e$ or ge-. Everything that follows, no matter how many syllables long, is unstressed. This can be translated into a system of syllabic trochaic feet, scanning from left to right. Examples can be taken from Old Germanic poetry (because poetic texts are the only texts that allow inference to stress; 1):

(1) Old Norse:

brótnuðu sthey broke<

gúllhyrndar >gold-hornedk

hvássara >more keenly< (Prymskviða, Norway ca. 900)

Old Saxon:

múnalica >lovely<

héleandoro >of the healing ones<

antfúnda sshe found

(Heliand, ca. 800)

Old High German:

mánunga sadmonition, adhortation<

gárawan sto prepare

gigárawan sto prepare

(Otfrid, ca. 800)

This kind of analysis has been largely abandoned, since Kiparsky started to loosen the stem-stress account, by formulating rules that predicted stress placement even in such notorious cases as the variable stressing of prefixes.

The majority of the analyses proposed since then have in common that they view stress as being assigned from right to left. Giegerich (1986, p. 31) proposes a rule which puts the main stress on the penultimate or antepenultimate syllable. His analysis basically allows feet of the form $(\mathrm{S}-\mathrm{W})$, and the antepenultimate stress results from adjunction of a final weak syllable to the stressed foot (2; taken from Giegerich 1986, p. 32 f.). It is not quite clear from his account, however, under what circumstances

1 Cf. e.g. Paul 1916, p. 152; traces still in Kiparsky 1966. 
the final syllable is adjoined and under what circumstances it simply is the weak part of the stressed foot.

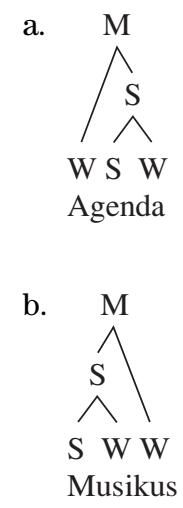

It is perhaps an inherent problem of this approach to metrics that the system is not as strict as it should be. In the study by Liberman and Prince (1977), which essentially is the basis of Giegerich's account, there are actually rules for the direction of the assignment of strong and weak units (p. 257, 266ff.); Giegerich possibly does not utilize such rules because doing so would generate a single invariable stress pattern, let us say that of (2b). In other words, a strict system with binary branching and a fixed direction of assignment would not be able to generate contrasts as in (2a) versus (2b). The abandonment of a strict direction of assignment is in danger of heavily overgenerating because such a system could apply the stress pattern of e.g. (2a) without problems to the word Musikus of (2b), so that the stress on this word would be Musikus, which is never found, unless clear conditions govern assignment variants can be formulated, which Giegerich seems unable to do.

Wiese (1996, p. 282) takes the same track: The default stress pattern in German is penultimate; antepenultimate stress is the outcome of extrametricality of the last syllable (p. 284). The metricality or extrametricality of the final syllable has to be stored in the underlying representations of the words in question, since he sees no way to make it predictable by a rule.

It is worth mentioning that nearly all examples of words long enough to allow the distinction between penultimate or antepenultimate stress are loanwords from Latin (as e.g. Músikus >musician (pejorative)<, Agénda >agenda<, Kalénder >calendar`) or Italian (e.g. Cémbalo >harpsichord<, $K a$ nóne >cannon<, Finále >final<). In these languages, however, the stress 
follows directly from the Latin stress system which is described in more detail in section 2.2. Here I give only a brief sketch: If the penultimate syllable is heavy, it receives stress; if not, the antepenultimate gets the stress. Working in a quantity-sensitive framework such as the one by Hayes (1995) gets the Latin loanword facts right without having to resort to diacritics as Wiese does. As a result, German might have two stress patterns, a Germanic one for native words and a Latinate one for foreign words. ${ }^{2}$ The alternative would be to stick to one stress pattern and try to get a more elegant account of it using a different theory of stress. So we have to look whether we can find evidence for one of the two alternatives in the history of German. This is what the main part of this essay is devoted to. On conceptual grounds it would be more economical to have as few competing stress patterns as possible, assuming that the language learner would rather have a single system that accounts for his/her input than two or more systems, if the single system is able to do the job as well, and so we should ask whether these systems could not be reduced in the end.

Here is the crucial point: Note that with the vast majority of words in German - that is: monomorphemic native words - it cannot be decided which of the proposed stress patterns they follow, as the Germanic and the Latin pattern would yield the same outcome. This is, because native monomorphemic words are usually only one syllable, sometimes two syllables long, and if they are disyllabic both, the Germanic initial and the Latinate penultimate stress pattern, would select the first of the two syllables as the stress-bearing element. To decide the default stress pattern we need ideally words satisfying all of the following conditions:

- they contain more than two syllables,

- they are monomorphemic (compounds obey the rules for phrasal stress, and derivatives also typically show influences connected with the selected suffixes),

- they are native (as with loanwords the stress system of the lending language might interfere), that means: either inherited from Protogermanic or borrowed at such an early stage and consequently nativized to such a degree that no language learner would come to the conclusion they are somewhat different from snormal native words.

The problem is that there simply are no monomorphemic native words in German with more than two syllables. The closest to it are a small number

${ }^{2}$ Actually, one would have to add a third system for the French loanwords with word-final stress (like generéll `generally`, Ingenieúr >engineer`). 
of derived nouns whose derivational setup is obscure to speakers of Modern German and consequently also to language learners. The words under discussion are to be found in $(3 a-c):^{3}$

$\begin{array}{lll}\text { (3) a. } & \text { Forélle } & \text { >trout } \\ \text { b. } & \text { Wachólder } & \text { sjuniper } \\ \text { c. } & \text { Holúnder } & \text { selder } \\ \text { d. } & \text { lebéndig } & \text { salive }\end{array}$

As the derivation is obscure, they can be assumed to be stored as monomorphemic stems in the mental lexicon. So they might qualify as monomorphemic stems with more than two syllables. There are a few words similar to the ones in (3) around (like Maßholder, >common maple ‘), but they are rare and therefore not taken into account for this discussion. Another interesting case, which I include, is the word lebendig (3d), a derivative with the adjective formation suffix - $i g$ from the present participle of leben >to live <. This word is noteworthy for several reasons. The morphological structure is exceptional, as the suffix -ig usually selects nouns as base; definitely nowhere else a deverbal adjective (as lebend, the base, cannot be a normal participle but must function here as an independently lexicalized adjective formed on the basis of the participle formation, as derivational suffixes arguably cannot take inflection forms of a word as base). Furthermore, the semantic interpretation of the word as a whole cannot computed compositionally, as -ig usually contributes merely something like sin the manner of $\mathrm{N}<$, where $\mathrm{N}$ is crucially a noun. The interesting thing from a phonological point of view is that the stress is on the penultimate syllable. The morpheme $-i g$ is otherwise a secondlevel morpheme which does not affect the word-stress (4). ${ }^{4}$

(4) a. Ábweg >way leading in the wrong direction< $\rightarrow$ ábwegig >deviant<

3 Forelle is a derivative which was formed sometime between the Proto-Germanic and the Old High German (OHG) period. It contains the root PIE *prk, meaning something like >speckled<, and a nominalizing suffix $-n$ - or $-l$ - (in OHG both suffixes were used). Cf. Sanskrit prśni, Greek perknós >speckled< and perké, >perch<. Holunder is formed with a suffix *-ter, which is cognate to English tree and Greek dorú >wooden shaft $\rightarrow$ spear $<$ and drús >oak $<$ and means >tree $<$ The first member of the compound goes back to PIE * kln, which denoted some kind of small tree (cognate with Russian kalina, which equates German Maßholder). Wachholder, in OHG also queckholder, is a compound of the word wach >awake and Holder, the reduced form of Holunder, but was not perceived as a compound after the OHG period (etymologies following Seebold 1995, s. vv.).

4 Cf. Kiparsky 1982; Wiese 1996, p. 291. 
The fact that these words, being stored as non-compounds, clearly show penultimate stress in Standard Modern German suggests that the default stress pattern indeed is penultimate rather than initial. ${ }^{5}$

Further evidence for the default stress pattern comes from experiments (reported in Wiese) in which subjects had to read foreign words and names without knowing the actual pronunciation. For that task words must be chosen which have a completely obscure derivation, Greek, Latin, French and English words are so common that the derivational morphemes or at least one member of a compound usually trigger the application of stress rules for derivatives and compounds. A good candidate for the task are Japanese words. The default hypothesis is that these words, although they tend to be very long, are perceived as monomorphemic. Wiese 1996, p. 280, cites data from such experiments which show a clear tendency towards penultimate or antepenultimate stress.

There are however problems. Antepenultimate stress is in Wiese's analysis the outcome of extrametricality of the last syllable, as in Hi-ró-shi$m a$ or in a proper name such as E-li-sa-beth. The distribution of these extrametrical syllables is however not predictable by a rule and must therefore be individually stored in the lexical entry of the words under question (Wiese 1996, p. $284 \mathrm{f}$.). If that is so, however, >new< words should never follow this stress pattern, as it is clearly non-default. But clearly they do. Let me cite as an example: A relatively recent brand name like Toshiba can be stressed by speakers who have not heard it otherwise (including myself) as tó-shi-ba. I was very puzzled when our system administrator at UPenn pronounced the name as to-shi:-ba, because it never occurred to me that this would be an option, too.

5 A problem appears if one takes words as in (5) into consideration.

(5) a. Náchtigall >nightingale<

b. Bräútigam >bridegroom<

These words are, like lebendig, exceptional with respect to the transparency of their composition. Although the first part of the compound is transparent, the second part is not, being neither an independent word in the language (as is the normal case with compounds) nor a productive suffix (Olsen 1986). So it is possible that these words would fall into the same category as the words in (3). It is hard to say, as the stress pattern is identical to that of transparent compounds, as in (6).

(6) a. Ápfelbaum >apple tree

b. Lándebahn >runway<

So it is doubtful to begin with whether words as in (5) really jeopardize the assumption that the default stress pattern is penultimate. Further below it will become clear that these words would not even pose a problem if they were perceived as monomorphemic. But there are more serious challenges for the hypothesis that the default stress system is penultimate. 
Obviously antepenultimate stress - or word-initial stress, that is again not quite clear from examples like toshiba - is a default option for some German speakers, which leads to the second, more serious problem with Wiese's analysis.

In this paper I wish to present a new account of default word stress in German which develops further Wiese's view by taking moraic considerations into account. My proposal crucially takes into consideration the history of word stress in German as far as we can trace it and follows directly from factors the language was exposed to during its history (section 2). It will become clear that German adopted the Latin stress system some time during the Early Modern German period. This was possible for two reasons. First, vowels in stressed syllables underwent obligatory lengthening, as a result of which the overwhelming majority of native German words could be more easily analysed according to both the Latin and the Germanic system. Second, the balance was tipped in favour of the Latin system because of a simultaneous large influx of Latin or Romance vocabulary. Finally (section 3) it will be shown how the system allows the usual loan word stress (which is final) observable today with a simple parameter setting.

\section{Historical development of German word stress}

\subsection{The need for a quantity-sensitive system}

The German and the Latin stress system will be dealt with later in the paper in more detail, but it might nevertheless be helpful to give a small overview of the two systems in comparison to each other.

The Germanic system is a quantity-insensitive system that presumably assigns syllabic trochees from left to right, and that recursively. That means that the main stress will always be on the first syllable of a word. Prefixes such as $b e$ - and $g e$ - don't count, possibly because they were regarded as forming a compound together with the verb.

The Latin system, on the other hand, is a quantity-sensitive system, assigning moraic trochees from right to left. The last syllable is extrametrical. Stress is assigned as soon as either two morae have been scanned, or before the word ends. Latin disyllabic words have the tendency to have two morae on the syllable which is to be stressed, but disyllabic words with short stressed vowel are not ruled out (such as e.g. virum >man.acc.<). Romance languages such as Italian and, to a certain degree, Old French follow the Latin stress pattern.

To determine the position of word stress I used a corpus of Middle High German and Early Modern German poetry, simply because in poetry one can determine the position of the stress in a straightforward way. 
In what follows I will attempt to demonstrate that the modern German situation is a consequence of a shift in the position of default stress over time. In rough outlines, the story goes as follows: German started with a root-initial stress system, which is still well preserved in Old High German and to some extent in Middle High German. After the first wave of (Old French) loanwords came into the language, there was a time of competition between the Old French default stress pattern (which is basically equivalent to the Latin stress system), and the native German initial pattern. Probably both systems coexisted in different domains: German stress pattern for native words, Latinate stress pattern for loanwords. In the $17^{\text {th }}$ century, that is, after the Humanistic age in which a second wave of loanwords, this time from Latin, entered German, the distinction between the two stress systems broke down and one default system was adopted, which corresponded roughly to the Latin system. The Latin-style sensitivity to the quantity of the penultimate syllable was adopted, too, and accounts for the way in which $>$ new $<$ words are stressed. The variation under that view is mostly due to the varying willingness of speakers of different dialects to alter the quantity of the penultimate syllable, which has direct consequences on the placement of stress. In the Southwestern dialects mentioned above, the choice is made in favour of faithfulness to the inherited quantity of the penultimate syllable, whereas in the other dialects the choice is made in favour of levelling the stress pattern to a penultimate system.

In what follows, I do not use Liberman and Prince's (1977) framework but Metrical Stress Theory as developed by Hayes (1986, 1995). The reason for this is as follows: As will become clear further below, there are very simple conditions under which various logically possible stress patterns in German - in trisyllabic words there are combinatorically three possibilities: X x x, $\mathrm{x}$ X x and $\mathrm{x} \times \mathrm{X}$, all of which are attested in German - can be assigned to German words. These conditions make explicit reference to the moraic structure of the word they attach to, particularly to whether the penultimate syllable one mora or two. In a system like Liberman and Prince's, it is not easily possible to make reference to the different syllable weights of the syllables which eventually are marked strong and weak. In any case, even if it were possible, a rule relating syllable weight and stress would have to be stipulated and does not follow from the way the system is set up. In Hayes' system, however, crucial use is made of morae insofar as they are important in foot construction, which again is the input for the first stress cycle. So the relationship between syllable weight and stress is intrinsic to the system, and therefore stress rules that make reference to syllable weight follow directly from the setup of the system. There are two ways to determine the position of word stress in historic stages of a 
language. One is to look for phonological processes typical of vowels in unstressed syllables, such as elision or reduction to a schwa. Such processes are rather common crosslinguistically $(7,8)$, and both have applied in the history of German (9). So for our survey of German we can use this inference, but with caution: If a vowel is elided, we can be sure that it was not stressed at the time at which elision occurs. If a vowel is reduced to a schwa, we might infer the same too, but reduction is more difficult to recognize than is elision, since schwa is not unambiguously represented, being written with the same grapheme $<\mathrm{e}>$ as the mid front vowel.

(7) a. Latin:

$$
\begin{array}{ll}
\text { perículum } \sim \text { períclum } & \text { >danger } \\
\text { fíhim } & \text { >he understood } \\
\text { /fihímna/ } \rightarrow \text { fhímna } & \text { >we understood }
\end{array}
$$

b. Palestinian Arabic: fíhim

(taken from Kager, p. 279)

(8) Latin: filia $\rightarrow$ Old French: fille >daughter

(9) a. OHG gelîch >likewise $\rightarrow$ NHG gleich

b. AGr Katharina (proper name) $\rightarrow$ Kathrin (usual German form)

c. OHG zwîvolôn >doubt<

$\rightarrow$ NHG zweifeln

d. OHG ziohan >pullk

$\rightarrow$ NHG ziehen

The other way is much more reliable and it is the way which I mostly use in this study. From the position of the words in question in poetry the stress pattern of these words can be easily and rather doubtlessly inferred. Since around 1200, German poetry shows a rather strict iambic or trochaic metrical system; in the Renaissance and in the Weimarer Klassik, more complex meters, influenced by Classical Greek poetry, are used, which are, however, easily identifiable. So the stress of any given word can be determined with relative certainty, as soon as it occurs in verse.

\subsection{First stage: Initial Stress}

Stress in Old High German seems to have followed the Proto-Germanic stress pattern: ${ }^{6}$ The first syllable of the stem received the main stress, no matter how many syllables followed (10). One could analyse the system as assignment of syllabic trochees from left to right; at the word level the first trochee would receive primary stress (11). With native words this was true also in the Middle High German period (10; Schmidt 1996, p. 226), so that it suffices to cite only Middle High German forms (see below [20][22]):

${ }^{6}$ Schmidt 1996, p. 48 f.; Paul 1916, p. 152; Wright 1907, p. 19. 
(10)
Old High German
Middle High German
a. fór(a)hana
fórhel, förhel, fore
strout<
b. hóluntar, hól(d)er
hólunter, holder, holr >elder<
c. wéhhalter
wáchsolder
jjuniper

(OHG and MHG word forms after Seebold)

(11)

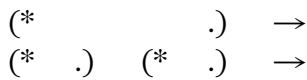
fo. ra. ha na

In Middle High German most words were subject to syncopation of unstressed vowels and apocopation of final vowels. As a result, most words ended up not exceeding two syllables. This is an important precondition for the opacity with respect to the stress system they follow, as in a word like fórahana nobody would ever dream of entertaining the thought that this word might follow the Latin stress pattern, whereas an analysis following the Latin stress pattern is at least applicable for the Middle High German form of the same word forhel.

\subsection{Second stage: Latinate stress on loanwords}

From the second half of the $12^{\text {th }}$ century onward a rather large influx of loanwords from Old French is observable. Although it presumably starts as a fashion in court circles, many of these words made their way into the vernacular of non-noble speakers, so it is reasonable to say that during the Middle High German period at least some of them became parts of all the registers of the vocabulary of all social strata.

A similar thing happened in English after the Norman Conquest, but with one crucial difference: Whereas in English these words were nativized to a high degree, including their stress pattern, which was altered in favour of the >Germanic< stress pattern of English, in German the words were borrowed including their stress pattern, which of course did not always conform to the inherited German stress pattern (12).
Early Middle High Original:
Attestation German loans:
a. âventiúre
OFrench aventúre
(e.g. GT 1, 166)
b. melodîe
OFrench melodíe
(e.g. GT 8, 4815)
c. organieret
OFrench organisér, organíssent
d. castêl
OFrench chastél
(e.g. GT 4, 2156) 
The first wave of loanwords still sometimes was adapted to the Germanic initial stress pattern. An example is Kemenate >room with a fireplace (from Medieval Latin/Italian caminata sidem<), which, although it is usually found with the Romance stress on the penultimate (Kemená:te), must have developed an initially stressed alternative form, which is still preserved in some place names (e.g. Kémnat, SE of Stuttgart). Note that the form shows the same reductions of the least prominent $2^{\text {nd }}$ and $4^{\text {th }}$ syllable vowels as OHG fórahàna to MHG forhel. ${ }^{7}$

This means that in German from the second half of the $12^{\text {th }}$ century onward there is quite a number of words which do not follow the Germanic stress pattern but rather the Old French stress pattern.

The Old French stress pattern seems to have been rather similar to the modern French stress pattern, with the difference that many syllables and segments that are not pronounced nowadays (e.g. word-final -ə, $3^{\text {rd }}$ person plural ending -ənt), still are pronounced. That is, the system shows a predictable change between final and penultimate stress: The stress falls on the final syllable, unless it contains a schwa, in which case it falls on the penultimate syllable. ${ }^{8}$ These facts can be captured best by assuming that the scan goes from right to left, and the foot is iambic, and the presence of a schwa in the final syllable causes it to be extrametrical (13).
a. $(. \quad *) \leftarrow$
(*) $(. \quad *) \leftarrow$
me. lo. di:
$\left.\begin{array}{lll}\text { b. } & (. & *\end{array}\right) \leftarrow$
a. ven. tiu. re

This system is totally incompatible with the Germanic system. One can, however, still recognize that it derives from the Latin system, which assigns stress as follows.

If the penultimate syllable is bimoraic (that is, either closed or with a long vowel), the primary word stress falls on the penultimate; if the penul-

7 Some words, such as âventiure >adventure< (12a), also adopted a more Germanlooking stress pattern (today it is Ábentèuer), but this might be due to the fact that folk-etymologically it is analysed as if it contained the German word Abend (>evening $<$ ). This is also the reason for the unexpected $/ \mathrm{b} /$, which cannot be the result of regular sound change, as there simply is not $\mathrm{a}>\mathrm{v} \rightarrow \mathrm{b} / \mathrm{V} \_\mathrm{V}<$ rule in German, rather on the contrary. If this view is correct, the stress pattern simply follows the rule of compounds (e.g. Ábendèssen >dinner<; compound structure: >evening+meal $<$ ).

8 Hollyman 1968, p. 10; Herslund 1976, p. 101. 
timate syllable is monomoraic, the stress falls on the antepenultimate. ${ }^{9}$ This might be analysed as a stress system in which moraic trochees are assigned from right to left, where the final syllable is always extrametrical (14; Hayes 1995, p. 92), and in which there is a ban on degenerate feet which prevents monomoraic syllables in penultimate position to form a foot (Hayes 1995, p. 95), unless there are not more syllables left for the scan (in disyllabic words such as virum >man.acc. $<$ or caput >head<). It should be noted, however, that such words are rare compared to disyllabic words with a bimoraic first syllable. Only in monosyllabic words, this does not hold (15); to assign at least one iamb is obviously higher ranked than to have the last syllable extrametrical. ${ }^{10}$

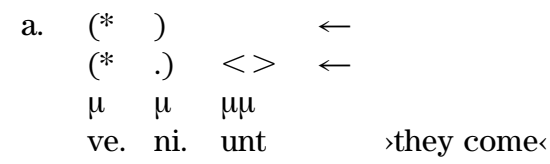

b. $(*) \quad \leftarrow$

$\left(\begin{array}{ll}* & .\end{array}\right)<$

$\mu \mu \quad \mu \quad \mu$

ma:. ri. a >oceans

c. (. *)

(*) $(*)<>\leftarrow$

$\mu \mu \quad \mu \mu \quad \mu \mu$

ad. ven. tus sarrivalk

$\left.\begin{array}{lll}\text { d. } & (. & * \\ & (* & .\end{array}\right) \quad(*)<>$

$\mu \quad \mu \quad \mu \mu \quad \mu$

o. ra. to:. re >orator (abl.)<

(15)
a. $\begin{array}{lll}(* & ) & \leftarrow \\ (* & ) & \leftarrow\end{array}$
$\mu \mu$
re:gs
>king

9 Maniet 1975, p. 33; Hayes 1995, p. 91.

10 The moraic trochees in monosyllabic words are all well-formed (following the condition in Hayes 1995, p. 69), as there are no monomoraic monosyllabic words in Latin, with the exceptions of the enclitics -que >and $<$, $-v e>$ or $<$ and -ne >(question marker)<, which do not count as independent words, however. 


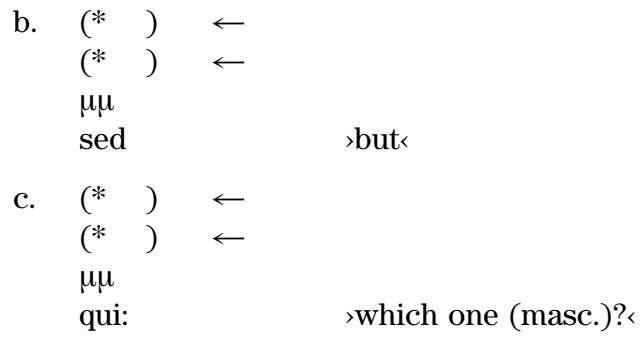

Some Latin loanwords were also adopted in this period, as e.g. (16), the borrowing of which must predate the Early New High German Diphthongisation, which happened, depending on dialect, between ca. 1200 and 1500 (Schmidt 1996, p. 94), as the long /u:/ of the Latin word appears as diphthong /au/.

(16) Kaldaúnen >intestines (from Medieval Latin caldu:na, which is a derivative of calidus >warm<: sintestines directly after slaughter, i. e. still warm<)

Middle High German consequently has several competing stress patterns, the native one (that is: stem-initial), and several foreign ones (most notably the Old French one). These systems, however, did not come into direct competition with each other, as the loan word stress seems to have been confined to the loanwords to which they originally belonged. Evidence for this cannot be gained from the vast majority of German words, as they would, because of their shortness and phonological structure, yield exactly the same accentuation, no matter whether under the native Germanic (17), the Old French or the Latin system (18; the word level is suppressed in these examples). Since in Middle High German all vowels in final syllables of polysyllabic native words are reduced to schwa, the Latin and the French system would give the same outcomes in all cases.

(17) a.

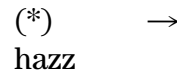

b. $\quad(* \quad.) \rightarrow$

lie. be

>love

(18) a. (*)

$\mu \mu$

hazz 


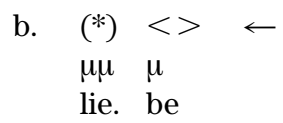

But note that some native German disyllabic words represent a less preferred option under a Latin stress system as there the stressed syllable is short, thus monomoraic (19). The Germanic stress assignment in (19a) has no problem with such words. The Latin system can parse these words, too, but the fact that such words are not particularly frequent in Latin suggests that they are somewhat exceptional within the Latin system (19b). One could conceive a scenario in which such derivations would crash if there were not a higher ranked constraint that forbids assigning no stress at all. It is perhaps fair to say that the Germanic system can cope better with such cases.

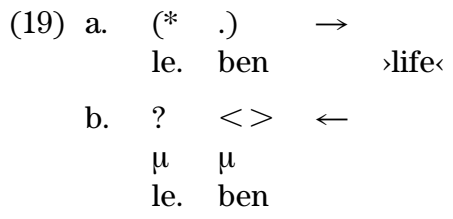

That native words in the Middle Ages did not follow one of the loanword systems but stuck to the >old< Germanic system is also clear from the stressing of trisyllabic quasi-monomorphemic words (that is, the words in [10]), which exhibited stable initial accent throughout Middle High German and Early New High German (with one exception; see below [26a]). The morphemes which led to the formation of forh-en/forh-el and holun-der in OHG or probably even in Proto-Germanic were not productive any more in Middle High German; that does not automatically entail that these words have been unanalyzable in Middle High German (we could only conclude that they were analyzable if they were still productive) but it suggests itself. As the word lebendig is morphologically ill-formed because the basis of the derivation is not of a sort which is ordinarily subcategorized by - $i g$, it is unclear how far it could have been accepted as a derivative. Remember that the development of its stress pattern in modern German is not in accordance with the stress pattern found usually with -ig. The examples in (20)(22) are from Lexer (1872-1878), with the exception of (20b). In poetry only the reduced, disyllabic forms fore/forhe (20) and holler/holder (21) occur, which alone suggest that the word was following the germanic stress pattern at that time, otherwise this syncope would have been impossible. The word lebendic shows up usually in its full form. The full form holunder, as well as the predecessors of modern Wacholder, only occurs in prose. The 
translations given for ex. (20)-(22) and (26ff.) are as close as possible to the original and do not pretend to be idiomatic English.

(20) a. báydü fórn und ásch

>both trout and perch

(Liedersaal CCII, 292 (vol. 3 p. 225) (undated, but MHG)

b. Grúndel, Séngel, Érlen vnd Kréssn

Fórhen, Esch, Rúppen, Hécht vnd Préssn

(Sachs/Schopper, p. 97,4; 1568)

c. Geseín mich hiút die vórhen zárt, der sól man níht vergézzen

stoday the tender trouts be blessed by me, one shall not forget them.<

(Colmar 68,13; before 1589)

(21) wánde die múse wéren

úz ir hólren gegán

$>$ because the mice

came out of their elder

(>Jüngere Judith $<$ : from a manuscript from Vorau/Steiermark, $12^{\text {th }}$ cent., ed. Diemer; 176,1)

(22) si sprách: `so rîche níemen ist lébendíg erkánt<

>she said: such a kingdom nobody alive has ever seen

(Kudrun 29,1)

\subsection{Third stage: Generalized Latin stress}

An important step on the path toward universal adoption of the Latin stress system in German was the lengthening of all stressed open-syllable vowels at the beginning of the Early New High German period (rendering le:ben out of leben; cf. e.g. Schmidt 1996, p. 289). It makes it easier to scan words like leben >life< or gabe >gift< under the Latin system, as they now conform fully to the Latin rules. So it is true even more than before that almost all native words - with exception of the few native trisyllabic words - could be analysed either way, according to the Germanic or the Latin stress system.

What is however the crucial step that made the Latin stress system attractive as a default system was the fact that, in the wake of humanism, many Latin loanwords floated into the language (some examples in [23]). Many of these words made their way into the vernacular, simply because they denoted concepts for which there were no native words, but which became increasingly important in everyday life (23a-b). Another source of such loanwords were French and Italian from the $16^{\text {th }}$ century onward $(23 c-e)$. First attestations following Seebold 1995: 
(23) a. Minute (15 ${ }^{\text {th }}$ cent.)

b. Sekunde (17 $7^{\text {th }}$ cent.)

c. Baracke (17 $7^{\text {th }}$ cent.)

d. Matratze (15 ${ }^{\text {th }}$ cent.)

e. Kanone $\left(16^{\text {th }}\right.$ cent.)

Words like in (23a-e) were adopted together with their Romance/Latin stress pattern. Since the Romance stress pattern was already in the German language as an option for loanwords, they did not become nativized with respect to stress, i. e. they did not adopt the Germanic initial stress. A further reason why they could keep their Latinate stress pattern might be that in the loan process their segmental structure could remain unchanged (and indeed did remain unchanged) as all segments in Latin, Italian or (at least for the most part) French borrowed words happen to be part of the phonemic inventory of German. That means that they could be borrowed as intact units, without need of adaptation or readjustment (differently from e.g. English). But if there is no readjustment taking place on the segmental level, it should not be surprising that there is no readjustment also on suprasegmental levels such as stress assignment. This will be explained in more detail further below.

But the more such words are used in the vernacular and thus become part of the basic vocabulary of everyone, the more >normal their stress pattern must seem to a German language learner. Remember that native words (with originally initial stress) receive stress on the same syllable under both systems anyway, that is: a system which puts the main stress on the stem initial syllable, and a system which puts the stress on the penultimate syllable, simply because native stems are almost never longer than two syllables (17)-(18). And speakers and language learners of German probably became prone for a quantity-sensitive system, as soon as Prokosch's Law, which says that stressed syllables in Germanic always must be heavy (see Booij 2009), began to apply in Early New High German times.

It is interesting in this context that a word like Kalénder was conformed to a Latinate stress pattern: The Latin form which is the basis of the borrowing is calendárium, the ending -ium was deleted and the word should have ended up as *Kalendár in German, if it was simply a matter of taking over the foreign word together with its foreign stress. But we see that the stress on Kalénder was readjusted - crucially not in accordance with the Germanic system (as e. g. English cálendar), but following the Latin stress rules. This indicates that the Latin stress rule existed as an independent system within German, powerful enough to alter non-conforming Latinate words.

With the heavy influx of loan word with three and more syllables, which are morphologically opaque to a German language learner, the language 
learner all of a sudden gets a whole new set of >long > >monomorphemic words such as the ones in (23) - as he/she will interpret opaque words as monomorphemic. As soon as a certain >critical mass of loanwords is reached, the language learner will take this as evidence that monomorphemic words in general follow a Romance-style stress pattern, since these >long ‘ monomorphemic words have underlying Romance stress (that is, in this case, penultimate). In other words: The default stress pattern becomes identical to the Latin one (cf. also Hayes 1995, p. 181). This is possible since there is no indication in native German words which could prevent this conclusion. A uniform default stress pattern is preferable on grounds of economy to two or three stress patterns with different domains, since with a uniform system the idiosyncratic diacritic marking which lexical entries must have to indicate which stress system they follow becomes obsolete.

Note that in a closely related language such as English these words were borrowed, too, but in contrast to German were nativized to a higher degree, so that their stress pattern resembled that of Germanic words (24):

$\begin{array}{ll}\text { (24) a. } & \text { ['kæ.len.də] } \\ \text { b. } & \text { ['mi.nit] } \\ \text { c. } & \text { ['se.kənd] } \\ \text { d. } & \text { ['bæ.rək] } \\ \text { e. } & \text { ['mæ.trəs] } \\ \text { f. } & \text { ['kæ.nən] }\end{array}$

A reason for the different treatment of loanwords of Romance languages into German on the one hand, and English on the other, might be that the phonetic inventory of German and at least Romance languages such as Latin, Spanish and Italian are relatively similar with respect to vowels. Despite its consonant-heavy reputation, the German phonetic inventory is actually rather rich when it comes to vowels, which is mainly due to two pecularities of the German vowel system: Vowel length is additionally marked by a [ \pm ATR]-distinction: All long vowels are automatically [+ATR], all short ones are automatically [-ATR]. ${ }^{11}$ From this it follows that for each vowel two alternants are available which differ with respect to their [ \pm ATR]-value. In addition, Old and Middle High German had a special rule of vowel harmony called >umlaut<, which turns non-front vowels to front vowels if they are followed by a syllable containing a high front vowel. In autosegmental terms, one could perceive this as spreading of a [-back]feature from any front vowel to the vowel constituting the peak of the

11 At least in native words; loanwords optionally contain short [+ATR]-vowels. Cf. Wurzel 1981. 
preceding syllable. These two processes render the German vowel inventory rather large: $[\mathbf{a}, \mathrm{a}, \mathbf{e}, \varepsilon$, ə, $\mathbf{i}, \mathrm{I}, \mathbf{o}, \supset, \boldsymbol{\emptyset}, \propto, \mathbf{u}, \mathrm{U}, \mathbf{y}, \mathrm{Y}] .{ }^{12}$ The vowel inventories of the relevant Romance languages, that is: the ones from which words were borrowed into German, viz. Latin, French and Italian, are subsets of the German inventory. For example: All Standard Italian vowels $[\mathrm{a}, \mathrm{e}, \mathrm{\varepsilon}, \mathrm{i}, \mathrm{o}, \mathrm{\jmath}, \mathrm{u}]^{13}$ are also part of the German phonetic inventory and were so also in the Middle High German period. For the most part the same goes for Old French vowels $[a, æ, e, \varepsilon$, , , i, o, (ø), o, (œ), u, (y)]. ${ }^{14}$ So loanwords, if pronounced as they were in their original language, are not perceived as exceedingly strange by German native speakers. Therefore a German native speaker may be more prone to adopt a word just as it is pronounced in its original language, because it does not stand in contradiction to his/her native phonetic categories. ${ }^{15}$

The English vowel inventory is quite different from that of German or the Romance languages in focus here. Many vowels, such as e.g. [ع:], [o:] or [a], disappeared in most dialects at the latest in the aftermath of the Great Vowel Shift and are consequently not part of the phonetic inventory of these English varieties. ${ }^{16}$ Thus the statement which went for German that the vowel inventory of e. g. Italian is a subset of the German vowel inventory does not hold for English. An English speaker, to be able to use a word like Medieval Latin minuta [mi'nu:ta] or Medieval French minute [mi'ny:tə] must first readjust its phonetic shape so that it fits his/her phonetic inventory. As the word is subject to some readjustment process anyway, often the stress pattern is eventually readjusted, too, ${ }^{17}$ for example in all the words in (24).

12 System following Wurzel 1981, p. 913 and Hall 2000, p. 68. [+ATR]-vowels in bold face, umlauted vowels in italics.

${ }^{13}$ Inventory following Kaze 1991, p. 165.

14 Old French system following Herslund 1976, p. 8. Later developed front round vowels are in brackets (Herslund 1976, p. 10, but cf. Calabrese 2000, p. 84, who suggests that /y/ already occurred in Old French). Nasalized vowels are of course an exception. But it should be noted that in some German dialects they are actually part of the phonetic inventory (e.g. Swabian, Palatian), so that nothing prevents them from being pronounced as they would have been in French, whereas in some other dialects (e.g. Swiss German, Bavarian and Austrian) nasalized vowels in French loanwords are pronounced as such, although they are not part of the phonetic inventories of these dialects. This is another indication that German tends to adopt loanwords without altering them too much.

15 This is of course not to say that every time a language borrows words that do not have to be adjusted on the segmental level the suprasegmental level is borrowed wholesale. Polish loans (Gr. mathemátika > Polish matematíka) are an example where that does not happen. All I say is, if one can borrow the segmental level intact, chances are higher that there won't be adjustment on the suprasegmental level than otherwise, i. e. if the word has to be adjusted anyway.

${ }^{16}$ For the Early Modern English vowel system cf. Chomsky/Halle 1968, p. 274.

17 Svensson 2001. 
Consequently, in German, in contrast to English, it is possible (or even the most common way) for loans to enter intact, both on the segmental and the suprasegmental level; the words are thus borrowed together with the stress pattern that was assigned to them in their parent language.

But as soon as the default stress pattern shifts from Germanic to Romance, words like in (3) - that is: the few quasi-monomorphemic native words with more than two syllables, become exceptions under that rule, and thus are likely to eventually follow the majority pattern. And the data indicates that this is exactly what happened. I rely on the data given in Grimm 1854-1971, as the editors of this dictionary (being good philologists) took pains to find the earliest attestation of each phenomenon they described, and they were sensitive to the stress shift, as they make clear in the lemmata of each of the words under discussion here. To get more data for the Early New High German period (as this might be the most interesting one for the purposes of this study) I read in addition through some works in verse by Fischart and Hans Sachs, used the concordance of the songs of Oswald von Wolkenstein and looked at what poetic texts were available in digital versions.

For two of the words (Wacholder, lebendig) we can find clear examples of penultimate stress from the mid $16^{\text {th }}$ century onward (26), but not before that. For Holunder the first attestation with penultimate stress comes only from the second half of the $18^{\text {th }}$ century (27). For an early attestation of Forelle with penultimate stress ${ }^{18}$ one could cite a poem by Schubart (28).

(25) Time span of attestations

\begin{tabular}{|c|c|c|c|c|c|c|c|c|c|}
\hline & \multicolumn{2}{|l|}{ Forelle } & \multicolumn{2}{|c|}{ Holunder } & \multicolumn{2}{|c|}{ Wacholder } & \multicolumn{3}{|c|}{ lebendig } \\
\hline Stress: & initial & penult. & initial & penult. & init. & penult. & init. & penult. & \\
\hline $1200 \mathrm{ff}$. & & & $(21)$ & & & & (22) & & \\
\hline $1250 \mathrm{ff}$. & & & $(-2)$ & & & & $(30)$ & (29) & 䇺 \\
\hline $1300 \mathrm{ff}$. & & & & & & & & & 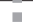 \\
\hline $1350 \mathrm{ff}$. & & & & & & & & (32b) & \\
\hline $1400 \mathrm{ff}$. & & & & & & & (31) & $(32 a)$ & \\
\hline $1450 \mathrm{ff}$. & & & & & & & 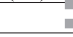 & & \\
\hline $1500 \mathrm{ff}$. & & & & & 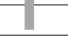 & & 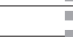 & & \\
\hline $1550 \mathrm{ff}$. & $(20 c)$ & & & & $(33 b)$ & $(26 a)$ & - & $(26 b)$ & \\
\hline $1600 \mathrm{ff}$. & & & & & & & 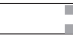 & & \\
\hline $1650 \mathrm{ff}$. & $(33 a)$ & & & & & & 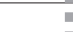 & & \\
\hline $1700 \mathrm{ff}$. & & & & & & & 正 & & \\
\hline $1750 \mathrm{ff}$. & & (28) & & (27) & & & $(33 c)$ & & \\
\hline
\end{tabular}

18 Grimm does not offer a testimonium primum. 
(26) a. er trégt ein hásen, hát in gfángen hínter dém wechóltergsteúd she carries a hare, did catch him behind the juniper-shrubbery

(Sebastian Wild: Tragödie von dem doctor, act III, v. 215; mid $16^{\text {th }}$ c.)

b. des schéchers glaúb war fést und bsténdig, dein glaúb der wánkt, ist nít lebéndig. sthe villain's belief was firm and steady; your belief quavers, is not alive.

(Clemens Stephani: Geistliche action; printed 1568)

(27) holúnderbüsche rágen um îhre grúft empór >juniper-bushes stand high around her grave.

(28) In eínem Bä́chlein hélle da schóß in fróher Eíl die laúnisché Forélle vorúber wíe ein Pfeíl. >In a clear brook there shot past, in a glad hurry, the fickle trout as an arrow.<

(Christian Friedrich Daniel Schubart; lived 1739-1791)

There is one Middle High German attestation for lebendig with clearly penultimate stress (29), but this might be only a last-resort scanning of a second-rate poet. Or perhaps variation was already possible with this one word. Still, we also have to admit that we do not really know whether this line had a regular iambic metre, as still in Friedrich von Suonenburg's time and after that >freie Senkung (>free trough $<$ ) was possible (see the second verse of example [29]). ${ }^{19}$ For Friedrich von Suonenburg obviously penultimate stress was not the only option, as the same poet also writes it in other places with >normak initial stress (30).

19 That means that the number of syllables between two metrical peaks can vary; only eventually strict alternation between peaks and troughs was consequently applied (Bumke 2000, p. 101; 106f.). 
(29) nein; ál die dír lebéndec sínt die nément durch êre gúot >no, all who are alive for you, receive goods through honour.

(Friedrich v. Suonenburg 1,115; floruit 1250-1275)

(30) swaz lébendec íst daz hât für wâr von sîner gábe ez lében.

>whatever is alive, truly has

its life from his gift.<

(idem 1,141)

The pattern that lebendig is not treated uniformly with respect to stress placement remains quite prevalent throughout the subsequent history (31)-(33). (31) gives a few attestations where we can be rather sure that the stress is initial, (32) ditto for places which are most probably scanned with stress on the second syllable.

(31) a. O reícher gót, küng áller reích, herr, fürste áller hérren, Der lébentig rót auf értereích vergángen únd noch wérden >o mighty God, king of all empires, Lord, lord of all lords, whose living crowd on earth has gone and will still be<

(Oswald v. Wolkenstein, 35,15; lived 1367-1445)

b. Ér wart lébendíg begráben >he was buried alive<

(Bühel 89,39; lived ca. 1360-1429/44)

c. lébendíg sy ín begruóbent salive they buried him<

(idem 98,13)

(32) a. solt eín lebéndigér ein tótten sláhen sshould a living one slay a dead one`

(idem 153,7)

b. Dár zuo, wér im mág geháben

lebéntigér fünf knáben

>In addition, who can have for himself

five living boys<

(Wittenwiler, v. 8554; floruit 1387-1410) 
Initial stress is attested for most of these words up to a relatively late date: for Forelle in the mid $17^{\text {th }}$ century, in its reduced and thus necessarily initially stressed form (33a), for Wacholder in the mid $16^{\text {th }}$ century (33b), and for lebendig even until the beginning of the $18^{\text {th }}$ century (33c).

(33) a. hier sáh man aál und wéls und aúserlésne schmérlen und pérsken, meíne lúst, und köstelíche férlen 'here one saw eels and sheat-fishes and excellent loaches and perches, my delight, and tasty trouts.

(Andreas Gryphius 2,64; lived 1616-1664)

b. sein weíb ihn mít eim léylach déckt und máchet ín die kámmer aúch von wácholtérberén ein raúch. >his wife covered him with a linen-cloth and makes in the chamber also smoke from juniper-berries.<

(Hans Sachs 17,265,31; lived 1494-1576)

c. lébendíg wird dér genénnet dén man gräbt, der reín und weích >alive one calls that one whom one digs for, who is pure and soft.<

(Barthold Hinrich Brockes; lived 1680-1747)

The question remains what exactly the Romance stress system which was adopted looked like. Wiese (1996, p. $284 \mathrm{ff}$.) is slightly on the wrong track when he only takes the quantity of the final syllable into account. Because the change between penultimate and antepenultimate stress in loanwords is not predictable from the quantity of the final syllable, he concludes that the last syllable is sometimes extrametrical, and leaves it to the lexical representation of each single word to indicate whether the final syllable in this or that word is extrametrical or not.

But he misses an important generalization. Note that not only words with penultimate stress were borrowed, but also words with antepenultimate stress (34). The distribution of penultimate and antepenultimate stress is completely predictable in the Latin system. Note that many of the words with antepenultimate stress come either directly from Latin (e.g. 28d) or from Italian (e.g. 28a), where the Latin system is still at work. In the loan process they retained their phonetic shape largely, including the Italian [+ATR]-vowels. 
(34) a. Rísiko >risk

b. Márzipan ${ }^{20}$

c. Cémbalo >harpsichord

d. Ímpetus

When we assume that not just a >weak system was borrowed (as Wiese seems to propose) but the Latin stress system as a whole, that is, including the condition on the weight of the penultimate syllable, words like those in (34) are no longer exceptional. Note that their penultimate syllable is in each case an open syllable with a short vowel, thus a monomoraic syllable.

Otherwise, if a >weak version of the Latinate stress, that is: put the stress in loanwords on the penultimate syllable, had been borrowed, we would have to analyze the examples in (34) as following the Germanic initial stress pattern. Then we need to account for why there is a group of words like the ones in (34) which is >more naturalized than other loanwords, and what defines this group. It would turn out that the defining property is just the short quantity of the penultimate syllable, that is a purely phonological parameter. As soon as this definiens is used to distinguish words following the penultimate stress pattern from ones following the Germanic stress pattern, we have to make reference to exactly the same properties as we had in using the Latin system as a whole. In this situation it is by Occam's razor preferable to choose the solution where one system produces the output over the solution in which there are two systems involved, whose respective domains are moreover defined by a completely predictable phonological parameter.

If that is so, the variation mentioned above with respect to the brand name Toshiba follows straightforwardly from variation in the status of the penultimate syllable. A speaker who interprets the penultimate syllable as monomoraic, will put the stress on the antepenultimate syllable (tó.shi.ba), whereas one that interprets the penultimate syllable as bimoraic, will put the stress on the penultimate (to.shi:ba, which represents the usual resolution.

Under this view the stress pattern of the words in (5) is expected even if they are not analysed as compounds but as monomorphemic. The second syllable in Nachtigall and Bräutigam is monomoraic and therefore not eligible to receive stress under the Latin system, or to be more precise: to head a trochaic foot, if the parsing goes from right to left and the last syllable is extrametrical.

${ }^{20}$ Attested (with this stress) e.g. in Fischart, Nacht Rab oder Nebelkräh, v. 2350 (Frankfurt [?] 1570). 


\section{Analysis of word-final stress}

There are two things that this analysis does not yet cover: Loanwords with final stress and remnant areas of >Germanic $<$ stress pattern. Let me start with the second problem.

Especially in Southern German dialects such as the varieties of Swiss German (including >Alemannisch < in Southern Baden and around the Lake of Constance) and Swabian (>Schwäbisch<, spoken in an area around and especially south of Stuttgart, which might be roughly defined by a line drawn between the cities Pforzheim-Nördlingen-Augsburg-Isny-Donaueschingen) there is a strong tendency to have the default stress on the initial syllable (36). Marc Matter (p.c.) assumes that this is a local feature which has its distribution peak at the very southern edge of the SwabianAlemannian dialect area and becomes less important the more north one gets. Dialects to the East of the German language area, such as MeißnischSaxon or Silesian, had not participated in the change leading away from word-initial stress in the time before WWII, as old native speakers of these dialects confirmed. Such a distribution is characteristic of a feature which has been replaced by another feature and survives only in hardly accessible regions and far away from the place where the new feature started. As non-initial stress is also a feature of the standard dialect it is hard to find the place where this feature originated, but we can exclude the regions in whose dialects this feature is not present. That leaves pretty much the Frankish and the Bavarian area as the only potential candidates. That the initial stress pattern is still productive in the Alemannian-Swabian dialect area is indicated by examples like (36c), uttered in the 1990 s by a shepherd on the Schwäbische Alb, which features a word that is present in the German language not longer than perhaps thirty years.

\begin{tabular}{llll} 
& standard: & \multicolumn{2}{l}{ Swiss (a,b), Hardcore } \\
& & \multicolumn{2}{l}{ Mountain Swabian (c): } \\
a. & generéll & génerell & >generally< \\
b. & Ingenieúr & Íngenieur & >engineer \\
c. & Biotó:p & Bíotop & >biotope
\end{tabular}

Note that under this view the dialect data of (36) could also just be an instantiation of Latinate stress. Note that the penultimate in all of these cases (and presumably in all comparable instances) is an open syllable with a short vowel, and need not be a relict of the old Germanic stress pattern. But what exactly would be the point of divergence between these two dialects which causes the variation?

To answer this question it turns out to be necessary to analyse words with word-final stress, which seems to be an accepted loan word stress 
pattern in modern German (but it is not an >unmarked< or >default< stress pattern for loanwords in general, as it is never adopted for morphologically opaque loanwords; cf. Hayes 1986). ${ }^{21}$ The stress on the words in (36) lies on the final syllable in standard German.

Obviously the point of divergence between the south-western dialects and Standard German is that a speaker of Standard German's mental representation of words like those in (36) has some diacritic marking which makes them eligible for final stress (that is, the construction of a final foot) whereas the representation in the mind of a speaker of a southwestern dialect does not have this diacritic marking so that these words fall subject to the default stress pattern.

What exactly would this diacritic be? Note that under our analysis of German word stress as basically following the Latin system the last syllable of words is by default extrametrical and the scanning process from right to left picks the rightmost syllable eligible for stress, which is the first heavy syllable it encounters or as last resort the second syllable left of the extrametrical syllable. In this system word final stress is excluded altogether.

Wurzel (1970) proposed a diacritic for these words which was basically [-native]. Let us try to come up with some further content of such a diacritic under the view of the analysis proposed here.

If a word bore a diacritic whose content would be basically: >last syllable not extrametrical< it would automatically receive final stress, as the scanning process would pick anyway the leftmost heavy syllable as the bearer of stress. Since all final syllables in words with final stress are bimoraic, either by being closed (ge.ne.rél >generally<), by having a long vowel (me.lo.di: >melody<) or most often by both (bi.o.tó:p, ge.ne.rá:l), it is the final syllable which happens to be the leftmost heavy syllable (37).

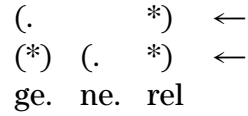

So the point in which speakers of Standard and South-West German differ is that South-West German speakers do not have the diacritic which ren-

21 Morphologically opaque loanwords are relevant, because words only can be analysed by German native speakers as monomorphemic if they have no clue as to their morphological structure. Remember that in determining the default stress pattern we have to confine ourselves to monomorphemic words or at least words which can be treated as such, as derivation and compounding in general imposes new conditions on stress which might overrun the actual default system. 
ders the final syllable metrical, or at least not all of them. Since this is a feature which operates on single words, the observable fact that the more to the Southwest one gets the more words follow the default stress pattern (Matter p.c.) is more easily explainable than if it were a competing initial stress pattern (because then the distribution should be regular and not anecdotal). Further evidence for the assumption that the Southwest German stresses of the Biotop, génerell type are not simply there by way of conforming to the (old) Germanic initial stress pattern comes from how our test words Holunder, Forelle and lebendig are stressed in the same dialects that have initial stress on e.g. generell: My informants confirmed that the stress on these words is as it is in Standard German, that is, on the penultimate syllable. ${ }^{22}$ If it were simply an emanation of an underlying initial stress, we would expect these words to be initially stressed, as they were in Middle High German. This evidence points to the correctness of the assumption that the difference between Southwest German dialects and the other dialects is not the preservation of the initial stress pattern, but the absence of the diacritic which in the other dialects cancels the extrametricality of the final syllable. As consequence, also in words which in the standard dialect and all non-Southwestern dialects are stressed word-finally the last syllable is extrametrical and thus the right-to-left scanning produces either penultimate (as in Forélle) or antepenultimate (as in génerell) stress.

\section{Conclusions}

In this paper I have tried to show that the default stress pattern of German simplex words - native and non-native words simultaneously - is basically identical with the Latin system. This is due to the fact that Latin loanwords or loanwords from languages which conformed to the Latin system as well, for a time offered virtually the only clue for language learners how to deal with polysyllabic simplex words in terms of stress, native words just being too short to allow for a decision between competing stress patterns. This state of affairs could arise firstly, because at the same time in which this happens we see a heavy influx of loanwords from languages that use a Latinate stress pattern (thus providing the language learner with a lot of evidence for the Latin stress pattern exclusively, as these words tend to be longer than two syllables and thus cannot be analyzed any more in both systems, the Latin and the Germanic one), and

${ }^{22}$ Wacholder is stressed on the first syllable, but it is most presumably viewed as a compound of wach + Holder in these dialects. 
secondly, because in German these loanwords could be borrowed without any later modifications (as they contained only segments that were present also in the German segment inventory), consequently also together with their intrinsic stress pattern, differently from many borrowings into e.g. English, where often such words fell subject to the native $>$ Germanic $<$ stress rules. ${ }^{23}$ The shift towards the Latin stress occurred around the $17^{\text {th }}$ century, to judge from the scarce data which is offered by the poetic scanning of the few native polysyllabic quasi-simplex words which exist in German. Most occurring words with stem-initial stress under this system can be reinterpreted as having Latin stress, too, as the Latin system would assign initial stress in those circumstances as well. Note that the initially stressed loanwords in Southwestern dialects have their stress conforming to the Latin pattern, too, whereas the standard dialect deviates from the default pattern in these instances, assigning final stress. As the Latin stress system involves an extrametrical final syllable, the point of variation between the standard and the Southwestern dialects would be whether the final syllable is counted in these circumstances as extrametrical or not. The Southwestern dialects are more regular in that respect, as they treat the final syllable always as extrametrical, whereas in the standard dialect in these words the last syllable counts as metrical and thus receives the stress by the usual leftward scanning, being always a bimoraic syllable.

\section{References}

\section{Sources}

Jost Amman, Das Ständebuch. 133 Holzschnitte mit Versen von Hans Sachs und Hartmann Schopper, ed. Manfred Lemmer, Leipzig 1975 (= Sachs/Schopper).

Hans von Bühel, Dyocletianus (www.fh-augsburg.de/ harsch/germanica/Chronologie/ $15 \mathrm{Jh} /)(=$ Bühel).

Deutsche Gedichte des XI. und XII. Jahrhunderts, ed. Joseph Diemer, Wien 1849 (= Diemer).

Edda Snorra Sturlusonar, ed. Finnur Jönsson, Copenhagen 1931.

Heliand und Genesis, ed. Otto Behaghel, Tübingen ${ }^{9} 1984$.

Meisterlieder der Kolmarer Handschrift, ed. Karl Bartsch, Hildesheim 1962 (= Colmar).

Die Nibelungen, ed. Paul Piper, Stuttgart, Berlin 1889 (= Lied vom Hürnen Seyfried).

Lieder Saal. das ist: Sammlung altteutscher Gedichte, ed. Reichsfreiherr v. Laßberg, St. Gallen 1846 (= Liedersaal).

${ }^{23}$ Of course not all loanwords; words like [ə.'dzen.də] >agenda for instance keep the Latinate stress pattern. The whole area of loan word stress in English is quite a matter of debate, which goes beyond the scope of this study (concerning the problem cf. e.g. Halle/Keyser 1971; Svensson 2001; Fikkert 2003; McCully 2003). 
Johann Fischart, Sämtliche Werke, ed. Hans-Gert Roloff [et al.], Bern 1993.

Gottfried von Straßburg, Tristan, ed. Rüdiger Krohn, Stuttgart 1993 (= GT).

Nibelungenlied - Kudrun, ed. Werner Hoffmann, Darmstadt 1972 (= Kudrun).

Die Lieder Oswalds von Wolkenstein, ed. Karl K. Klein, Tübingen 1975 (= Oswald von Wolkenstein).

Otfried von Weißenburg: Evangelienbuch, ed. Wolfgang Kleiber, Tübingen 2006.

Christian Friedrich Daniel Schubart: Gedichte. Aus der deutschen Chronik, ed. Ulrich Karthaus, Stuttgart 1978.

Heinrich Wittenwiler, Der Ring (www.fh-augsburg.de/ harsch/germanica/Chronologie/ $15 \mathrm{Jh} /)$ (= Wittenwiler).

All other quotations are taken from Grimm: (26a) vol. 27, col. 58; (266) vol. 12, col. 425; (27) vol. 10, col. 1762; (29) vol. 12, col. 425; (30) ibid.; (33a) vol. 3, col. 1897; (33b) vol. 27, col. 57; (33c) vol. 12, col. 425 .

\section{Secondary literature}

Booij, Geert 2009: Lexical Storage and Phonological Change, in: Kristin Hanson and Sharon Inkelas (ed.), The Nature of the Word. Studies in Honor of Paul Kiparsky, Cambridge, Ma., p. 487-505.

Bumke, Joachim 2000: Geschichte der deutschen Literatur im hohen Mittelalter. $4^{\text {th }}$ edition, München.

Calabrese, Andrea 2000: The Feature [Advanced Tongue Root] and Vowel Fronting in Romance, in: Lori Repetti (ed.), Phonological Theory and the Dialects of Italy, Philadelphia, p. 59-88.

Chomsky, Noam, and Morris Halle 1968: The Sound Pattern of English, New York.

Fikkert, Paula 2003: The prosodic structure of prefixed words in the history of West Germanic, in: Paula Fikkert and Haike Jacobs (ed.), Development in Prosodic Systems, Berlin, p. 315-348.

Giegerich, Heinz J. 1986: Metrical Phonology and Phonological Structure, Cambridge.

Grimm, Jacob, and Wilhelm Grimm 1854-1971: Deutsches Wörterbuch, Leipzig.

Hall, T. Alan 2000: Phonologie. Eine Einführung, Berlin.

Halle, Morris, and Samuel J. Keyser 1971: English Stress. Its form, its growth, and its role in verse, New York.

Hayes, Bruce 1986: Review of Giegerich (1986), in: Journal of Linguistics 22, p. $229-$ 235.

- 1995: Metrical Stress Theory, Chicago.

Herslund, Michael 1976: Structure phonologique de l'ancien français, Copenhagen.

Hollyman, Kenneth J. 1968: A short descriptive grammar of Old French, Auckland.

Kager, René 1999: Optimality Theory, Cambridge.

Kaze, Jeffery W. 1991: Metaphony and two models for the description of vowel systems, in: Phonology 8, p. 163-170.

Kiparsky, Paul 1966: Über den deutschen Akzent, in: Studia grammatica 7, p. 69-98.

- 1982: Lexical Phonology and Morphology, in: In-Seok Yang (ed.), Linguistics in the morning calm, Seoul, p. 3-91.

Lexer, Matthias 1872-1878: Mittelhochdeutsches Handwörterbuch, Leipzig.

Liberman, Mark Y., and Alan Prince 1977: On Stress and Linguistic Rhythm, in: Linguistic Inquiry 8, p. 249-336.

Maniet, Albert 1975: La Phonétique historique du Latin, Paris.

McCully, Chris 2003: Left-hand word-stress in the history of English, in: Paula Fikkert and Haike Jacobs (ed.), Development in Prosodic Systems, Berlin, p. 349393.

Olsen, Susan 1986: Deutsche Wortbildung, Stuttgart. 
Paul, Hermann 1916: Deutsche Grammatik. Band I: Geschichtliche Einleitung Lautlehre, Halle.

Schmidt, Wilhelm 1996: Geschichte der deutschen Sprache, 7. Auflage, Stuttgart.

Seebold, Elmar 1995: Kluge - Etymologisches Wörterbuch der deutschen Sprache, 23. Auflage, Berlin.

Svensson. Ann-Marie 2001: Germanic vs French Stress in Disyllabic Loan Words in English, in: Gothenburg Studies in English 81, p. 123-129.

Wiese, Richard 1996: The phonology of German, Oxford.

Wright, Joseph 1907: Historical German Grammar, Oxford.

Wurzel, Wolfgang U. 1970: Der Fremdwortakzent im Deutschen, in: Linguistics 56, p. $87-108$.

- 1981: Phonologie: Segmentale Struktur, in: Karl Erich Heidolph et al. (ed.), Grundzüge einer deutschen Grammatik, Berlin, p. 898-993.

FRANKFURT AM MAIN

Augustin SPEYeR 